\title{
Mechanical properties of natural hydraulic lime-based mortars
}

J. Lanas ${ }^{\text {a }}$, J.L. Pérez Bernal ${ }^{\mathrm{b}}$, M.A. Bello ${ }^{\mathrm{b}}$, J.I. Alvarez ${ }^{\mathrm{a}, *}$

a Departamento de Química, Universidad de Navarra, 31080 Pamplona, Spain

b Departamento de Química Analítica, Universidad de Sevilla, Apdo. 1065, 41012

Sevilla, Spain

$\mathbf{N}^{\circ}$ of pages: 36

No of tables: 6

$\mathbf{N}^{\circ}$ of figures: 9

Keywords: C: Compressive Strength. B: Calcium-Silicate-Hydrate (C-S-H). C: Carbonation. A: Curing. D: Pore Size Distribution.

Please, send all correspondence to:

Dr. José I. Alvarez Galindo

Dpto. de Química

Fac. de Ciencias

Universidad de Navarra

$\mathrm{C} /$ Irunlarrea s/n

31.080 Pamplona (Navarra)

Spain

Phone: 34948425600

Fax: 34948425649

E-mail: jalvarez@unav.es 


\title{
Mechanical properties of natural hydraulic lime-based mortars
}

\author{
J. Lanas ${ }^{\text {a }}$, J.L. Pérez Bernal ${ }^{\mathrm{b}}$, M.A. Bello ${ }^{\mathrm{b}}$, J.I. Alvarez ${ }^{\mathrm{a}, *}$ \\ a Departamento de Química, Universidad de Navarra, 31080 Pamplona, Spain

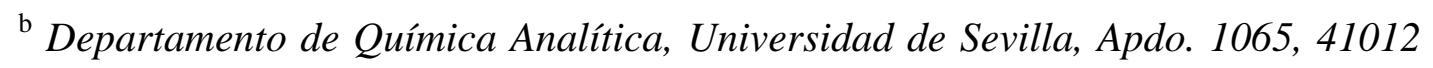 \\ Sevilla, Spain
}

\begin{abstract}
: 180 different mortars made with a natural hydraulic lime and different kinds of aggregates were prepared in order to be used in restoration works. The factors affecting the mechanical behavior have been studied at long-term test. Compressive and flexural strengths of the specimens were discussed according to curing time, binder:aggregate ratios, attributes of the aggregates and porosity.

Three phases of hardening have been established as a function of the chemical composition: $\mathrm{C}_{3} \mathrm{~S}$ contributes to the strength at early ages. $\mathrm{C}_{2} \mathrm{~S}$ and the carbonation process give their strengths at long term. Specimens with larger binder amounts have shown higher porosity and strength. The characteristics of the aggregates have been correlated with the strength and porosity. Limestone aggregates contribute to the strength. Rounded shaped aggregates, increasing large pores, cause a strength reduction, so their use is not advisable. Aggregates with small grain size show a good cohesion at the interface improving the strength.
\end{abstract}

Keywords: C: Compressive Strength. B: Calcium-Silicate-Hydrate (C-S-H). C: Carbonation. A: Curing. D: Pore Size Distribution.

* Tel.: + 34948 425600; Fax: + 34948 425649; e-mail: jalvarez@unav.es 


\section{Introduction}

Sabbioni and co-workers [1,2] define in a binding material the term "hydraulic" in relation to two specific properties: the capacity of hardening when water is added to the dry binder, and the property to harden under water. A hydraulic binder is obtained adding to the lime (air-hardening binder) different materials that confer it the aforementioned properties.

The content of impurities, as silica $\left(\mathrm{SiO}_{2}\right)$ and alumina $\left(\mathrm{Al}_{2} \mathrm{O}_{3}\right)$ mainly, is the responsible for this effect [1-3]. An hydraulic lime can be produced burning at 1000$1250{ }^{\circ} \mathrm{C}$ limestones with a high content of clays (6.5-20\%) or mixing clay minerals with finely grounded pure limestones [4]. The reaction between the lime and $\mathrm{SiO}_{2}$ and $\mathrm{Al}_{2} \mathrm{O}_{3}$ leads to the formation of calcium silicates and aluminates. Hydration of these compounds provides consistency to the mortar paste, which hardens [5]. The final temperature of burning can not exceed $1250{ }^{\circ} \mathrm{C}$, because sintering occurs at higher temperatures. In the cement production, limestone and clay are calcined at temperatures exceeding $1400^{\circ} \mathrm{C}$ : a clinker is formed due to the sintering process

In an empirical way, hydraulic lime mortars have been used since centuries. The Phoenicians employed these binders in Jerusalem $\left(10^{\text {th }}\right.$ century BC). The Greeks added Santorin's earth to the mortar: this volcanic powder provided hydraulic properties, and the resulting mortars were water-resistant [6]. However, the Romans achieved a great knowledge about the preparation and applications of these hydraulic mortars and they spread their use. The joining of volcanic sand from Pozzuoli left, aside the well-known characteristic name for these materials, very durable mortars which properties have been highlighted by several authors [5,7-10].

In the $18^{\text {th }}$ century the work of Smeaton with an Aberthan's limestone started the scientific knowledge about the hydraulic limes. Actually, as Sabbioni et al. state [1], 
hydraulic lime was the link with the Portland cement, developed in the mid-19th century. The industrial development of ordinary Portland cement (OPC), as well as the derivative products, quickly displaced the hydraulic lime for building technology. Nowadays, hydraulic lime-based mortars are present in historic structures (both as original components and restoration materials) and in buildings dating from 19th and beginning of 20th centuries, which have an unquestionable cultural interest [10-12].

In the framework of the restoration process, the compatibility between the new repair mortars and the original components has been emphasized [13]. This compatibility must be reflected in chemical, physical and structural aspects. An extensive damage to the ancient masonry due to the use of cement-based mortars in the restoration works has been proved [14-16].

Therefore the use of new natural hydraulic lime-based mortars in restoration projects attains here its foundation. The best compatibility with the old material is one of the reasons, but it can also be stated that natural hydraulic lime (NHL) (coming, for example, from a natural quarry) is not subjected to production changes due to economic factors.

Besides these reasons, there is a different composition of the hydraulic phases between NHL and cement, due to sintering occurred during the cement production. Calcium silicates (mainly $\mathrm{C}_{3} \mathrm{~S}$ ) and calcium aluminates $\left(\mathrm{C}_{3} \mathrm{~A}\right.$ and $\left.\mathrm{C}_{4} \mathrm{AF}\right)$ are formed during sintering. In NHL, $\mathrm{C}_{2} \mathrm{~S}$ is the major hydraulic phase [17]. Gehlenite $\left(\mathrm{C}_{2} \mathrm{AS}\right)$ can still be observed, which indicates the lower temperature reaches in the burning process of NHL $\left(<1200^{\circ} \mathrm{C}\right) \cdot \mathrm{C}_{3} \mathrm{~S}, \mathrm{C}_{3} \mathrm{~A}$ and $\mathrm{C}_{4} \mathrm{AF}$ could be also detected in NHL, in small amounts due to a local overheating in the limekiln. Calcium hydroxide $(\mathrm{CH})$ also appears. In cement, free $\mathrm{CaO}$ is combined during sintering, and no free $\mathrm{CH}$ is checked. Gehlenite does not 
appear in the final cement either [18]. Obviously, these different compositions have an influence on the final properties of the binder.

A critical property for the adequate choice of a new repair mortar is the strength. A strong repair mortar (as cement based mortars) is not advisable because masonry structures show same degree of movement resulting from creep or thermal effects, so a repair mortar should be capable of accommodating movement $[13,19]$.

In the literature, systematic studies about the mechanical behavior of hydraulic limebased mortars have not yet been executed. Some previous works have highlighted the gaps in the knowledge about these materials [1,2,15].

This paper focuses on the factors affecting the mechanical behavior in different natural hydraulic lime-based mortars. The prepared mortars have been studied at long-term tests and the influence of curing time, binder:aggregate ratios, nature and particle size distributions of the aggregates, and finally porosity, has been discussed. The knowledge about these factors will allow to select or prepare a natural hydraulic lime-based mortar for restoration works.

\section{Experimental work}

\subsection{Mortars}

A natural hydraulic lime has been used to prepare the mortars. This hydraulic lime is a commercial lime of the class HL5 according to European normative [20], and it has been supplied by Chaux Bruyeres (Saint-Front-sur-Lémance, Fumel). Table 1 gives its chemical characterization (according to European Standard) [21] and Figure 1 shows its X-ray diffractogram.

In this work, silico-calcareous and pure limestone aggregates were used. The characteristics and chemical composition, the mineralogical characterizations and 
particle size distributions are introduced in Table 2, Table 3 and Fig. 2 respectively. CTH Navarra (Navarra, Spain) has provided the aggregates, which have controlled granulometry.

The binder:aggregate ratios (B/Ag) prepared were (1:1), (1:2), (1:3), (1:4) and (1:5), by volume. Volume proportions of compounds were converted in weight to avoid measurement imprecision on mixing process.

The mortar pastes were obtained using the amount of water required to achieve normal consistency and a good workability (measured by the flow table test) (Table 4 presents these results together with the amount of water added) [22]. The mixer used was a Proeti ETI 26.0072 [23]. Aggregate and lime were blended for 5 min. Water was then added and mixed for 5 min in low speed, and finally for $1 \mathrm{~min}$ in high speed. The mortars were molded in prismatic 40x40x160 mm casts [24] and demolded $72 \mathrm{~h}$ later. The pastes were slightly compacted in a specific device [23] to remove any air bubbles and voids. Curing was executed in ambient laboratory conditions until the test day (RH $60 \pm 10 \%$ and $\left.20 \pm 5^{\circ} \mathrm{C}\right)$.

9 specimens of each B/Ag ratio were prepared, 180 specimens have been studied altogether. By using the techniques descried below, tests and analyses were performed after curing times of 3, 7, 28, 91182 and 365 days. Two specimens were tested at the intermediate curing period (28, 91 and 182 days), but only one at 3, 7 and 365 days. The reported results were an average value of the similar specimens, and the variation coefficients were below $15 \%$ in compressive strength results.

\subsection{Mechanical evaluation}


The three-point flexural test was performed on the mortar specimens using a Frank/Controls 81565 compression machine at low rates of loading (4 mm/min). The device of flexural strength determination is an Ibertest IB 32-112V01.

Compression strength test was carried out on the two fragments of each specimen resulting of the previous flexural test. The rate of loading was $10 \mathrm{~mm} / \mathrm{min}$, and the device of compression strength determination is a Proeti ETI 26.0052.

\subsection{Mineralogical analysis}

A significant portion of each specimen was ground in an agate mortar. Samples were taken from the core and the edges of the mortar specimens to avoid differences in the carbonation depth.

The mineralogical phases contained in the samples were determined by means of X-ray diffraction (XRD) using a Bruker D8 Advance diffractometer (Karlsruhe, Germany), according to the diffraction powder method, with a CuKa1 radiation and $0.02^{\circ} 2 \theta$ increment and $1 \mathrm{~s} \cdot \mathrm{step}^{-1}$, sweep from 2 to $90^{\circ} 2 \theta$. The results were compared with the ICDD database.

\subsection{Thermal analysis}

Differential thermal and thermogravimetric analysis (DTA-TG) were carried out using a simultaneous TGA-sDTA 851 Mettler Toledo thermoanalyser (Schwerzenbach, Switzerland) using alumina crucibles, with holed lids, at $20^{\circ} \mathrm{C} \min ^{-1}$ heating rate, under static air atmosphere, from ambient temperature to $1200^{\circ} \mathrm{C}$.

\subsection{Infrared spectroscopy}


Powdered samples were analyzed by FT-IR spectroscopy, using the $\mathrm{KBr}$ pellet. The analysis was performed with a Nicolet-FTIR Avatar 360, with OMNIC E.S.P. software. The resolution was $2 \mathrm{~cm}^{-1}$ and the spectra were the result of averaging 100 scans. All measurements were carried out at $20 \pm 1^{\circ} \mathrm{C}$ and ca. $40 \% \mathrm{RH}$.

\subsection{Pore structure and microstructure}

The pore structure was evaluated in two ways in specimens after 365 days of curing, in order to assure a high level of carbonation. Two methods were used:

a) Open porosity measurement: the total porosity is expressed as $\mathrm{P}$, in percent, and is determined according to the water saturation test [25] with a hydrostatics balance.

b) Pore size distribution is evaluated using the mercury intrusion porosimetry technique with a Micromeritics 9320 Poresizer mercury porosimeter which automatically registers pressure, pore diameter, intrusion volume and pore surface area.

Scanning electron microscopy (SEM) in a Digital Scanning Microscope DSM-940 A Zeiss was used for microscopic observations of the microstructure of the mortars.

\section{Results and discussion}

\subsection{Influence of curing time}

Fig. 3 shows the curves of compressive and flexural strength vs. curing time. From these results, three phases of mortar's hardening clearly differentiated can be checked.

- $\quad$ In the early ages (up to 28 days) the mortars extend to a $50 \%$ of their maximum value of strength, for the mortars with high content in lime ((1:1) and (1:2) B/Ag ratios), and close to a 85-90 \% for the (1:3), (1:4) and (1:5) B/Ag ratios. In this 
period, the mortars lose the water excess. Fig. 4 shows weight losses in the prepared mortars until 28 days, except specimen (1:1) with higher B/Ag ratio. This (1:1) mortar needs more water than the others to achieve a good workability during its preparation (Table 4), and it shows a weight loss until 91 days.

The strength is due to the hydration of several hydraulic compounds that form hydrated calcium silicates (commonly CSH phases) as the main compounds [26].

By means of XRD and FT-IR studies, it can verify hydraulic phases in NHL used. The occurrence of $\mathrm{C}_{3} \mathrm{~S}$ and $\mathrm{C}_{2} \mathrm{~S}$ is shown in Fig. 1, although the peaks of both compounds appear overlapped. The infrared absorption spectrum of NHL obtained is displayed in Fig. 5. The spectrum shows a strong broad band in the $1200-800 \mathrm{~cm}^{-1}$ region. Maxima absorptions were checked at around 883, 908 and $940 \mathrm{~cm}^{-1}$, typical for anhydrous tricalcium silicate [18,27]. Also strong absorption bands at $\sim 850$, 1000 and $1112 \mathrm{~cm}^{-1}$ (which is also due to the sulphates presence) are attributed to anhydrous dicalcium silicate [18]. $\mathrm{C}_{3} \mathrm{~S}$ is formed during sintering process, due to a local overheating at $\mathrm{T}>1250^{\circ} \mathrm{C}$ [17]. Therefore the amount of $\mathrm{C}_{3} \mathrm{~S}$ must be low in NHL, as can be checked with the aforementioned determinations. $\mathrm{C}_{3} \mathrm{~S}$ hydrates quickly and the strong strength increment at early ages (up to 28 days) can be attributed to this hydration [17].

At early ages, also $\mathrm{C}_{3} \mathrm{~A}$ reveals some interest. An almost instantaneous set can be proved in mixtures with high $\mathrm{C}_{3} \mathrm{~A}$ content. $\mathrm{C}_{3} \mathrm{~A}$ accelerates the hydration of $\mathrm{C}_{3} \mathrm{~S}$ [17].

However, its strength contribution is negligible. In the NHL used, chemical analysis (Table 1) reveals $5.42 \%$ of $\mathrm{Al}_{2} \mathrm{O}_{3}$. By means of $\mathrm{XRD}$, gehlenite $\left(\mathrm{C}_{2} \mathrm{AS}\right)$ has been checked (Fig. 1). This compound can be determined in hydraulic limes but not in cements [18]. No $\mathrm{C}_{3} \mathrm{~A}$ has been identified by $\mathrm{XRD}$, but it could be masked due to its 
low amount. Also by FT-IR $\mathrm{C}_{3} \mathrm{~A}$ could be masked, but the absorption band at 850 $\mathrm{cm}^{-1}$ (Fig. 5) could be attributed at different compounds, $\mathrm{C}_{3} \mathrm{~A}$ among them. So, the occurrence of $\mathrm{C}_{3} \mathrm{~A}$ can not be totally rejected.

Thermal analysis (TG/DTG) shows, in the range of $200^{\circ}-600^{\circ} \mathrm{C}$ the weight losses attributed to the dehydration of hydraulic compounds. Table 5 presents, as an example, the results of percentage of water bound to CSH-CAH compounds, determined by TG, in all specimens made with Ag-1. This water loss gives evidence to the presence of $\mathrm{H}_{2} \mathrm{O}$ bounded to hydraulic components (CSH, CAH) $[9,10,28]$.

At medium-term (since 28 to 182 days, approximately), the mortars start to gain weight (Fig. 4). This is of the fact that the water excess has been eliminated and the mortars have begun the carbonation process (Eq. 1). However, this weight increment is still low, so it can be concluded that carbonation is also low and by no means complete.

$$
\mathrm{Ca}(\mathrm{OH})_{2}+\mathrm{CO}_{2} \rightarrow \mathrm{CaCO}_{3}+\mathrm{CO}_{2} \quad \text { Eq. } 1
$$

Furthermore, the $\mathrm{C}_{3} \mathrm{~S}$ hydration produces new calcium hydroxide $(\mathrm{CH})$. This new $\mathrm{CH}$ formed must carbonate later on. In Table 5 it appears the ratio $\mathrm{CaCO}_{3}(\%)$ / $\mathrm{Ca}(\mathrm{OH})_{2}(\%)$ obtained by TG at different test days in all the specimens made with Ag-1. This ratio has been calculated in order to avoid the modifications in percentage terms due to the high amount of calcite, and it allows to make comparisons between the different curing times. This calcite contribution is clearly larger in specimens made with Ag-3 and Ag-4. It can be checked that the quotient decreases until 91 days, so the $\mathrm{CH}$ amount increases. This fact proves the $\mathrm{CH}$ formation due to $C_{3} S$ hydration, as it has been stated in some previous works [29], where $\mathrm{CH}$ increases in a $\mathrm{C}_{3} \mathrm{~S}$ pure paste until 28 days. This age for maximum $\mathrm{CH}$ is 
lower than the results of this work. But, the hydration of $\mathrm{C}_{2} \mathrm{~S}$, clearly determined in the specimens tested, also produces $\mathrm{CH}$, as will be discussed. Taking into account the slower $\mathrm{C}_{2} \mathrm{~S}$ hydration than $\mathrm{C}_{3} \mathrm{~S}$ hydration, new $\mathrm{CH}$ formed can show a maximum later on [30].

In this period the compressive strength of the mortars only increases slightly (Fig. 3) owing to: (i) the $\mathrm{C}_{3} \mathrm{~S}$ hydration could be practically finished, because $\mathrm{C}_{3} \mathrm{~S}$ contributes to the strength at early periods and it is present in small amount in NHL; (ii) at this moment, the $\mathrm{C}_{2} \mathrm{~S}$ has not a great influence to the strength because the major part of its contribution occurs from 28 days onwards, with maxima values at long-term ages [17]; (iii) carbonation has not yet a significant influence. Lime mortar carbonation is a very slow process (it is well-known that lime mortars can take many years in their total carbonation) [3], and its strength contribution is lower than the hydraulic components.

- At long-term curing time (between 182 and 365 days), the strength of (1:1) and $(1: 2)$ mortars increases again due to:

(i) the contribution of the $\mathrm{C}_{2} \mathrm{~S}$ to the strength. The $\mathrm{C}_{2} \mathrm{~S}$ is the major hydraulic phase in NHL, which reacts more slowly during the hydration (Eq. 2) [30];

$$
2\left(2 \mathrm{CaO} \cdot \mathrm{SiO}_{2}\right)+4 \mathrm{H}_{2} \mathrm{O} \rightarrow 3 \mathrm{CaO} \cdot 2 \mathrm{SiO}_{2} \cdot 3 \mathrm{H}_{2} \mathrm{O}+\mathrm{Ca}(\mathrm{OH})_{2} \quad \text { Eq. } 2
$$

The $\mathrm{C}_{2} \mathrm{~S}$ hydration at long-term curing time can be proved by the decrease of the ratio $\mathrm{CO}_{2}(\%)$ / water bound to $\mathrm{CSH}(\%)$ determined by TG between 182 and 365 days in Table 5. This increment of water attributed to CSH gives evidence to the hydration of the hydraulic phases.

(ii) at long-term test the carbonation degree (due to the portlandite transformation into calcite (Eq. 1) reaches significant values: its contribution to 
the strength can be clearly checked. Table 5 shows a sharp rise in the $\mathrm{CaCO}_{3}(\%)$ / $\mathrm{Ca}(\mathrm{OH})_{2}(\%)$ ratio between 182 and 365 days in (1:1) and (1:2) specimens; and (iii) also the new $\mathrm{CH}$ formed during $\mathrm{C}_{2} \mathrm{~S}$ and $\mathrm{C}_{3} \mathrm{~S}$ hydrations has influence. More calcite can be produced than from the initial $\mathrm{CH}$ in NHL, increasing the strength. Some of new $\mathrm{CH}$ amount can also crystallize, inside of CSH structure and well sheltered, and this fact has been related to improve mortar strength $[9,10,28]$.

On the contrary, it can be observed (Fig. 3) that (1:3), (1:4) and (1:5) ratios do not show any strength increment in this last period. The low NHL amount in these mortars can be considered the responsible to this fact because: (i) the free $\mathrm{CH}$ is almost carbonated, as can be checked in Table 5: (1:3), (1:4) and (1:5) specimens show very slight changes in the $\mathrm{CaCO}_{3}(\%) / \mathrm{Ca}(\mathrm{OH})_{2}(\%)$ ratio between 182 and 365 days; (ii) the strength contribution of $\mathrm{C}_{2} \mathrm{~S}$ is practically negligible on account of this very low amount in these specimens.

\subsection{Influence of binder:aggregate ratio}

In all specimens tested, mortars with more binder content show the highest compressive and flexural strengths (Fig 3). This fact can be proved at any time and irrespective of the type of aggregate used. A binder decrease in the mortar has reduced its strength.

From the results, B/Ag ratios (1:3), (1:4) and (1:5) have shown similar strength. As a general behavior, these specimens do not increase their strength due to the low NHL amount, as previously discussed in section 3.1.

These higher strengths for specimens with larger binder amounts disagree with same references that state: (i) the (1:3) ratio is the suitable mixture for repair mortars, due to its highest strength [14]; (ii) the occurrence of some cracks due to the shrinkage when the binder amount increase above of (1:3) ratio [16]; (iii) the increment of strength 
when aggregate content increases [31]. In the tested specimens, no macroscopic cracks have been observed. The shrinkage in all B/Ag ratios of the mortars has shown low values, ranging from 0.5 to $0.7 \%$ length change in $(1: 1) \mathrm{B} / \mathrm{Ag}$ mortars. In fact, an increment in the percentage of binder fraction allows to a denser pore structure in the mortar nucleus, imparting higher strength [28], This behavior is very similar to cement mortars: binder increase in the mix improves strength [13].

It can be stated that NHL is a mixture, in different proportions, made of $\mathrm{CH}$ and pozzolanic materials. These materials, in order to give strength components and to exhibit their activity, require $\mathrm{CH}$. The formation of $\mathrm{CSH}$ in these materials explains their strength, as a result high binder proportions improves the strength. In this sense, cements with pozzolanic materials enhance their strength when $\mathrm{CH}$ is incorporated to the mix due to $\mathrm{CSH}$ formation [32].

In order to establish the mechanical requirements of the specimens to be used in restoration works, Fig. 6 shows the lower strength for each class of mortar according to the European Standards [33]. At 28 days, all (1:1) B/Ag mortars are M5. For (1:2) B/Ag mortars, specimens made with limestone aggregates (Ag-3 and Ag-4) are also M5. B/Ag specimens with low binder percentage exhibit low strengths.

\subsection{Influence of the aggregate characteristics.}

There are several attributes of the aggregates that have any influence on the mechanical behavior of the specimens. Firstly, the grain size distribution of the aggregates used. An adequate grain size distribution (Fig. 1) has allowed developing a high strength in the mortar. Ag-3 and Ag-4 aggregates have presented a grain size distribution without rock fragments (gravel $>2 \mathrm{~mm}$ ) [34]. Mortars made with these aggregates have shown the highest flexural and compressive strength values (Fig. 3). However, Ag-1 and Ag-2, 
which contain pebbles into their composition, they have improved less mortar strength than Ag-3 and Ag-4. This influence of grain size distribution of the aggregates in the strength shows an agreement with previous works [35].

Also chemical composition shows importance: Ag-1 and Ag-2 are of silico-calcareous nature, while Ag-3 and Ag-4 are pure limestone aggregates (Tables 2 and 3). Therefore the nature of the aggregate has shown to be a factor affecting the mortar strength: it can be clearly established that the use of siliceous aggregates has produced a strength reduction. Limestone aggregates have improved higher strengths. The similarity existent between a calcitic binder matrix and a limestone aggregate structure could be related to this increase of strength. In this sense, during portlandite carbonation, the calcite of the aggregate provides nucleating sites for the crystal growth. This syntaxial growth process develops strength enhancing the binder-aggregate interface $[3,36]$.

Apart from these factors, the shape of aggregate grains appears to have some influence. As a matter of fact, specimens with Ag-2 have shown higher strengths than specimens whit Ag-1. Given that grain size distributions and nature are very similar, the strength reduction when Ag-1 was used should be due to another reason. Made with rounded grains, Ag-1 has hindered a suitable adherence and the obtaining of a packed structure [3]. Ag-2 has improved mechanical strength because of the good packing of its angular shapes, which were produced during the crushing stone process.

\subsection{Porosity influence}

The influence of the porosity on strength of cement-based materials has been widely discussed [13]. Also in lime-based mortars porosity has a great importance if the mechanical behavior is considered. In cement-based mortars, a porosity increment when binder amount decreases causes a strength reduction. From the results of open porosity 
(Table 6) it can be concluded that, contrary to cement-mortars, in the specimens tested large binder amounts are related to a porosity increment. NHL contributes more to the porosity than aggregate, while OPC contributes less to the porosity than aggregate, and it justifies the inversion of the porosity trend.

As it has previously discussed in 3.2., a binder increment leads to a strength increment. The parallel porosity increase due to the large amounts of binder does not lead to a strength drop. This is related to: (i) the different mortar composition, because large binder amounts give more CSH phases, so the strength increases. As an example, Fig. 7 shows the SEM observations for (1:1) B/Ag mortar made with Ag-3: and CSH phases can be observed at the binder-aggregate interface, improving mortar strength; (ii) a porosity increment in lime mortars allows a faster and more complete carbonation [32,37]: the transformation of portlandite into calcite leads to a strength increase.

Figure 8 shows the pore size distribution in specimens with different B/Ag ratios for all the aggregates used, after 1 year of curing. From the results, it can be checked that NHL contribution shows pores around $0.3 \mu \mathrm{m}$ of diameter. This fact can be proved because, in all cases, irrespective of the aggregate used, the highest B/Ag ratios have shown sharper peaks in this pore size. Also these specimens, with high binder content, have presented an increment in small diameter pores $(0.1$ to $0.01 \mu \mathrm{m})$. Pores with diameter between 0.6 to $7 \mu \mathrm{m}$ are attributed to the limestone aggregates contribution: an increment in this percentage of pores is observed when aggregate amount increases, i.e. more aggregate amount means a great peak in this pore size. Also in Ag-1 and Ag-2 this fact occurs due to the chemical composition of these aggregates, with a certain amount of calcite (Table 3).

In Figure 8, also it can be observed that large pores (diameter between 7 and $100 \mu \mathrm{m}$ ) show a percentage increment when aggregate content rises. These large pores evident 
mechanical repercussions: the strength values decrease when the B/Ag ratio decreases, i.e. when the percentage of large diameter pores increases. The specimens with Ag-1, especially the 1:1 B/Ag ratio, presents the highest values of large pores, (peak around $50 \mu \mathrm{m})$. These pores can be due to a bad cohesion between the binder and the aggregate. The rounded shape of this Ag-1 does not allow a good adhesion at the interface of aggregate-matrix, and the strength drop. This influence of the aggregate shape on the strength is also proved by Ag-2 results (Fig. 8). No peak from pores with diameter of 50 $\mu \mathrm{m}$ is observed, although very similar composition between Ag-1 and Ag-2 was established. Therefore, as discussed in 3.3., the shape of the aggregate is the responsible for this increment of large pores: Ag-2 is angle-shaped, and it allows a better packed structure. Also Ag-3 and Ag-4 are angle-shaped, and no large pores are checked. For Ag-4, its grain size distribution lead to a lower amount of pores with diameter between 7 and $100 \mu \mathrm{m}$ than Ag-3. The small grain size in Ag-4 contributes to a more compact matrix embedded with aggregate grains. Fig. 9 shows a good cohesion at the binderaggregate interface in SEM observations.

\section{Conclusions}

(1) About the curing time, three phases of hardening have been clearly established in NHL mortars, as a function of their chemical composition.

(2) At early ages, $\mathrm{C}_{3} \mathrm{~S}$ hydration has been identified as the responsible for the strength increment. At medium-term, compressive strength shows slight changes. At longterm (1:1) and (1:2) B/Ag mortars present a new strength increment attributed to $\mathrm{C}_{2} \mathrm{~S}$ hydration and portlandite carbonation. (1:3), (1:4) and (1:5) B/Ag specimens do not show any strength increment due to the low NHL amount in these mortars. 
(3) Specimens with more binder content show the highest compressive and flexural strengths.

(4) Aggregate attributes have been discussed: a suitable grain size distribution of the aggregate has allowed to develop high mortar strength. Limestone aggregates exhibits the highest strength; and this fact has been related to the syntaxial growth of the calcite, which develops strength enhancing the binder-aggregate interface.

(5) In the specimens tested, large binder amounts show a porosity increment but also a strength increment: more CSH phases and a faster and more complete carbonation can give an explanation to these facts.

(6) The use of a rounded shaped aggregate increases the large pores (50 $\mu \mathrm{m})$ due to the bad cohesion between the binder and the aggregate, and it causes a strength reduction. Angle shaped aggregates lead to a better packed structure, a large pores decrease and a strength increment.

\section{Acknowledgements}

The present study was supported by the Spanish Ministerio de Ciencia y Tecnología, Plan Nacional de Investigación, Desarrollo e Innovación Tecnológica (I+D+I) program, Project MAT 2000-1347.

The authors would like to thank José María Galech (CTH) Navarra and Chaux Bruyeres for the material supplied. We are also grateful to Dr. Jordana for its help with SEM observations.

\section{References}

[1] C. Sabbioni, A. Bonaza, G. Zappia, Damage on hydraulic mortars: the Venice Arsenal, Journal of Cultural Heritage 3 (2002) 83-88. 
[2] C. Sabbioni, G. Zappia, C. Riontino, M.T. Blanco-Varela, J. Aguilera, F. Puertas, K. Van Balen, E.E. Toumbakari, Atmospheric deterioration of ancient and modern hydraulic mortars, Atmos Environ 35 (2001) 539-548.

[3] O. Cazalla, Morteros de cal. Aplicación en el patrimonio histórico, Unpublished PhD thesis (in Spanish), Universidad de Granada, Granada, 2002.

[4] J.I. Alvarez, Caracterización de morteros en monumentos históricos navarros, Unpublished PhD thesis (in Spanish), Universidad de Navarra, Pamplona, 1997.

[5] F. Rassineux, J.C. Petit, A. Meunier, Ancient analogues of modern cement: calcium hydrosilicates in mortars and concretes from Gallo-Roman Thermal Baths of Western France, J Am Ceram Soc 72 (6) (1989) 1026-1032.

[6] J.I. Alvarez, A. Martín, P.J. García Casado, Historia de los morteros, Boletín del Instituto Andaluz del Patrimonio Historico 13 (1995) 52-59.

[7] R. Malinowski, Concretes and mortars in ancient aqueducts, Concrete International 1 (1979) 66-76.

[8] V. Furlan, P. Bisseger, Les mortiers anciens. Historie et essais d'analyse scientifique, Revue suisse d'Art et d'Archéologie 32 (1975) 1-14.

[9] A. Moropoulou, A. Bakolas, K. Bisbikou, Physico-chemical adhesion and cohesion bonds in joint mortars imparting durability to the historic structures, Constr Build Mater 14 (2000) 35-46.

[10] A. Moropoulou, A. Bakolas, K. Bisbikou, Investigation of the technology of historic mortars, Journal of Cultural Heritage 1 (2000) 45-58.

[11] G. Biscontin, M.P. Birelli, E. Zendri, Characterization of binders employed in the manufacture of Venetian historical mortars, Journal of Cultural Heritage 3 (2002) 31-37. 
[12] V. Fasssina, M. Favaro, A. Naccari, M. Pigo, Evaluation of compatibility and durability of a hydraulic lime-based plasters applied on brick wall masonry of historical buildings affected by rising damp phenomena, Journal of Cultural Heritage 3 (2002) 45-51

[13] M.J. Mosquera, D. Benitez, S.H. Perry, Pore structure in mortars applied on restoration. Effect on properties relevant to decay of granite buildings, Cem Concr Res 32 (2002) 1883-1888.

[14] A. Moropoulou, A.S. Cakmak, G. Biscontin, A. Bakolas, E. Zendri, Advanced Byzantine cement based composites resisting earthquake stresses: the crushed brick/lime mortars of Justinian’s Hagia Sophia, Constr Build Mater 16 (2002) 543552.

[15] C. Rodriguez-Navarro, E. Hansen, W.S. Ginell, Calcium hydroxide crystal evolution upon aging of lime putty, J Am Ceram Soc 81 (11) (1998) 3032-3034.

[16] O. Cazalla, C. Rodriguez-Navarro, E. Sebastian, G. Cultrone, Aging of lime putty: effects on traditional lime mortar carbonation, J Am Ceram Soc 83 (5) (2000) 1070-1076.

[17] F.M. Lea, The chemistry of cement and concrete, Edward Arnold Ltd., Glasgow, 1970.

[18] H.F.W. Taylor, Cement Chemistry, Academic Press, New York, 1990.

[19] A.W. Hendry, Masonry walls: materials and construction, Constr Build Mater 15 (2001) 323-330.

[20] EN 459-1, Building Lime. Part 1: Definition, specification and conformity criteria (2001).

[21] EN 196-2, Methods of testing cement. Part 2: Chemical Analysis of cement (1994). 
[22] En 1015-3, Methods of test for mortar for masonry. Part 3: Determination od consistence of fresh mortar (by flow table) (1999).

[23] EN 196-1, Methods of testing cement. Part 1: Determination of strength (1995).

[24] EN 1015-11, Methods of test for mortar masonry. Part 11: Determination of flexural and compressive strength of hardened mortar (1999).

[25] RILEM, 1980. Recommended tests to measure the deterioration of stone and asses the effectiveness of treatment methods, Mater Struct 13 (1980) 175-253.

[26] P.J.P. Gleize, A. Müller, H.R.Roman, Microstructural investigation of a silica fume-cement-lime mortar, Cement Concrete Comp 25 (2) (2003) 171-175.

[27] A.H. Delgado, R. M. Paroli, J.J. Beaudoin, Comparison of IR Techniques for the characterization of construction cement minerals and hydrated products, Appl Spectrosc 50 (8) (1996) 970-976.

[28] A. Moropoulou, G. Biscontin, A. Bakolas, K, Bisbikou, Technology and behavior of rubble masonry, Constr Build Mater 11 (2) (1997) 119-129.

[29] K.L. Lin, K.S. Wang, T.Y. Lee, B.Y. Tzeng, The hydration characteristics of MSWI fly ash slag present in $\mathrm{C}_{3} \mathrm{~S}$, Cem Concr Res 33 (7) (2003) 957-964.

[30] K.S. Wang, K.L. Lin, T.Y. Lee, B.Y. Tzeng, The hydration characteristics when $\mathrm{C}_{2} \mathrm{~S}$ is present in MSWI fly ash slag, Cement Concrete Comp 25 (2003) In Press.

[31] Guía práctica de la cal y el estuco, Editorial de los Oficios, Leon, 1998.

[32] P. Mira, V.G. Papadakis, S. Tsimas, Effect of lime putty addition on structural and durability properties of concrete, Cem Concr Res 32 (2002) 683-689.

[33] EN 998-2, Specification for mortar masonry. Part. 2: Masonry mortar (2001).

[34] USDA. United State Departament of Agriculture. Natural Rersources Conservation Service. Soil Survey Laboratory Methods Manual, Natl. Soil Surv. Cent. SSIR 42 (1996) p. 693. 
[35] G. Baronio, L. Binda, N. Lombardi, The role of brick pebbles and dust in conglomerates based on hydrated lime and crushed bricks, Constr Build Mater 11 (1997) 33-40.

[36] M. Heikal, M.H. El-Didamony, M.S. Morsy, Limestone-filled pozzolanic cement, Cem Concr Res 30 (2000) 1827-1834.

[37] D.R. Moorehead, Cementation by the carbonation of Hydrated Lime, Cem Concr Res 16 (1986) 700-708. 
Table 1. Chemical analysis of the hydraulic lime $\mathrm{e}^{\mathrm{a}, \mathrm{b}}$.

\begin{tabular}{|c|c|c|c|c|c|c|c|c|c|}
\hline Lime & I. L. (\%) & $\mathrm{SiO}_{2}(\%)$ & $\mathrm{CaO}(\%)$ & MgO (\%) & $\mathrm{Al}_{2} \mathrm{O}_{3}(\%)$ & $\mathrm{Fe}_{2} \mathrm{O}_{3}(\%)$ & $\mathrm{SO}_{3}(\%)$ & $\mathrm{Na}_{2} \mathrm{O}(\%)$ & $\mathbf{K}_{2} \mathbf{O}(\%)$ \\
\hline $\begin{array}{c}\text { Lime H } \\
\left.\text { (Hidraulic }{ }^{\circledR}\right)\end{array}$ & 15.00 & 12.57 & 54.26 & 7.65 & 5.42 & 1.16 & 2.13 & 0.34 & 1.35 \\
\hline
\end{tabular}

${ }^{\mathrm{a}}$ Percentages related to original dry lime.

b The methods specified by the European Standard EN-196 were followed for the chemical analyses. 
Table 2. Chemical analysis of the aggregates ${ }^{\mathrm{a}}$.

\begin{tabular}{|c|c|c|c|c|c|c|c|c|c|c|}
\hline Aggregate & $\begin{array}{l}\text { I. L. } \\
(\%)\end{array}$ & $\begin{array}{c}\mathrm{SiO}_{2} \\
(\%) \\
\end{array}$ & $\begin{array}{c}\mathrm{CaO} \\
(\%) \\
\end{array}$ & $\begin{array}{c}\text { MgO } \\
(\%)\end{array}$ & $\begin{array}{c}\mathrm{R}_{2} \mathbf{O}_{3}{ }^{\mathrm{C}} \\
(\%) \\
\end{array}$ & $\begin{array}{l}\mathrm{SO}_{3} \\
(\%)\end{array}$ & $\begin{array}{c}\mathrm{Na}_{2} \mathrm{O} \\
(\%) \\
\end{array}$ & $\begin{array}{l}\mathrm{K}_{2} \mathrm{O} \\
(\%) \\
\end{array}$ & Origin & Shape \\
\hline Ag-1 & 15.06 & 57.69 & 19.00 & 1.53 & 5.69 & 0.08 & 0.36 & 0.48 & Pebbles & $\begin{array}{c}\text { Rounded } \\
\text { edges }\end{array}$ \\
\hline Ag-2 & 9.35 & 72.29 & 9.84 & 1.50 & 6.00 & 0.10 & 0.37 & 0.50 & $\begin{array}{c}\text { Crushed } \\
\text { stones }\end{array}$ & $\begin{array}{c}\text { Angular } \\
\text { edges }\end{array}$ \\
\hline Ag-3 & 43.10 & 0.49 & 52.83 & 2.28 & 1.14 & 0.57 & 0.07 & 0.05 & $\begin{array}{l}\text { Crushed } \\
\text { stones }\end{array}$ & $\begin{array}{c}\text { Angular } \\
\text { edges }\end{array}$ \\
\hline Ag-4 & 43.14 & 0.12 & 52.11 & 3.05 & 1.10 & 0.34 & 0.06 & 0.04 & $\begin{array}{l}\text { Crushed } \\
\text { stones }\end{array}$ & $\begin{array}{c}\text { Angular } \\
\text { edges }\end{array}$ \\
\hline
\end{tabular}

a Percentages related to original dry aggregate.

b The methods specified by the European Standard EN-196 were followed for the chemical analyses.

${ }^{\mathrm{c}} \mathrm{R}_{2} \mathrm{O}_{3}$ expresses the percentage of $\mathrm{Fe}, \mathrm{Al}$ and $\mathrm{Ti}$ as oxides. 
Table 3. Results of X-ray diffraction in aggregates.

\begin{tabular}{|c|c|c|}
\hline Aggregate & $\begin{array}{c}\text { Calcite } \\
\left(\mathrm{CaCO}_{3}\right) \\
\text { ICDD 05-0586 }\end{array}$ & $\begin{array}{c}\alpha-Q u a r t z \\
\left(\mathrm{SiO}_{2}\right) \\
\text { ICDD 85-798 } \\
\end{array}$ \\
\hline Ag-1 & $*$ a & $* * \mathrm{~b}$ \\
\hline Ag-2 & $*$ & $* *$ \\
\hline Ag-3 & $* * * \mathrm{c}$ & $\mathrm{T}^{\mathrm{d}}$ \\
\hline Ag-4 & $* * *$ & $\mathrm{~T}$ \\
\hline $\begin{array}{l}\text { a } 10-50 \% \\
\text { b } 50-90 \% \\
\text { c }>90 \% \\
\text { d } \text { Traces }(<5 \%)\end{array}$ & & \\
\hline
\end{tabular}


Table 4. Water added to the mixtures (mL) and flow table test results (mm).

\begin{tabular}{|c|c|c|c|c|c|c|}
\hline & & \multicolumn{4}{|c|}{ Aggregate } & \\
\hline & & Ag-1 & Ag-2 & Ag-3 & Ag-4 & \\
\hline \multirow{10}{*}{ 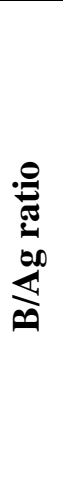 } & \multirow{2}{*}{$1: 1$} & 855 & 985 & 825 & 925 & $\mathrm{H}_{2} \mathrm{O}(\mathrm{mL})$ \\
\hline & & 159 & 139 & 156 & 152 & Flow test $(\mathrm{mm})$ \\
\hline & \multirow{2}{*}{$1: 2$} & 710 & 875 & 915 & 868 & $\mathrm{H}_{2} \mathrm{O}(\mathrm{mL})$ \\
\hline & & 142 & 139 & 170 & 155 & Flow test $(\mathrm{mm})$ \\
\hline & \multirow{2}{*}{$1: 3$} & 690 & 850 & 785 & 845 & $\mathrm{H}_{2} \mathrm{O}(\mathrm{mL})$ \\
\hline & & 141 & 138 & 156 & 157 & Flow test $(\mathrm{mm})$ \\
\hline & \multirow{2}{*}{$1: 4$} & 650 & 850 & 780 & 840 & $\mathrm{H}_{2} \mathrm{O}(\mathrm{mL})$ \\
\hline & & 117 & 141 & 154 & 157 & Flow test $(\mathrm{mm})$ \\
\hline & \multirow{2}{*}{ 1:5 } & 600 & 820 & 775 & 845 & $\mathrm{H}_{2} \mathrm{O}(\mathrm{mL})$ \\
\hline & & 128 & 131 & 150 & 154 & Flow test $(\mathrm{mm})$ \\
\hline
\end{tabular}


Table 5. TGA for hydraulic lime mortars with Ag-1.

\begin{tabular}{|c|c|c|c|c|c|c|}
\hline $\begin{array}{c}(\mathrm{B} / \mathrm{Ag}) \\
\text { ratio }\end{array}$ & $\begin{array}{c}\mathrm{Ca}(\mathrm{OH})_{2}{ }^{\mathrm{a}} \\
(\%)\end{array}$ & $\begin{array}{c}\mathrm{CaCO}_{3}{ }^{\mathrm{b}} \\
(\%)\end{array}$ & $\begin{array}{l}\text { Water bound } \\
\text { to } \operatorname{CSH}^{\mathrm{c}}(\%)\end{array}$ & $\begin{array}{l}\mathrm{CaCO}_{3}(\%) / \\
\mathrm{Ca}(\mathrm{OH})_{2}(\%) \\
\end{array}$ & $\begin{array}{c}\mathrm{CO}_{2}(\%) / \\
\text { Water bound to CSH (\%) }\end{array}$ & Day \\
\hline \multirow{6}{*}{$\ddot{\ddot{H}}$} & 5.06 & 46.90 & 1.13 & 9.26 & 18.30 & 3 \\
\hline & 8.90 & 38.46 & 1.91 & 4.32 & 8.84 & 7 \\
\hline & 9.76 & 35.14 & 2.23 & 3.60 & 6.95 & 28 \\
\hline & 8.91 & 37.57 & 2.00 & 4.18 & 8.53 & 91 \\
\hline & 4.86 & 47.12 & 1.95 & 10.16 & 14.02 & 182 \\
\hline & 3.07 & 52.36 & 1.97 & 17.05 & 11.72 & 365 \\
\hline \multirow{6}{*}{$\stackrel{\sim}{\sim}$} & 2.01 & 43.73 & 0.79 & 21.79 & 24.42 & 3 \\
\hline & 3.67 & 43.57 & 1.20 & 11.89 & 15.93 & 7 \\
\hline & 4.75 & 42.92 & 1.21 & 9.03 & 15.66 & 28 \\
\hline & 5.66 & 40.17 & 1.28 & 7.10 & 13.82 & 91 \\
\hline & 2.52 & 45.85 & 1.05 & 18.18 & 19.30 & 182 \\
\hline & 1.53 & 47.63 & 1.31 & 31.13 & 16.07 & 365 \\
\hline \multirow{6}{*}{$\stackrel{9}{\ddot{r}}$} & 0.33 & 51.16 & 0.72 & 28.46 & 31.11 & 3 \\
\hline & 1.96 & 48.82 & 0.84 & 24.85 & 25.58 & 7 \\
\hline & 2.19 & 49.84 & 0.79 & 22.79 & 27.66 & 28 \\
\hline & 2.25 & 49.10 & 0.79 & 21.79 & 27.24 & 91 \\
\hline & 0.89 & 51.38 & 0.85 & 57.88 & 26.67 & 182 \\
\hline & 0.91 & 52.69 & 0.83 & 58.01 & 25.95 & 365 \\
\hline \multirow{6}{*}{$\stackrel{\leftrightarrow}{\oplus}$} & 1.46 & 48.21 & 0.78 & 33.02 & 27.32 & 3 \\
\hline & 1.67 & 54.00 & 0.64 & 32.29 & 37.32 & 7 \\
\hline & 2.02 & 49.02 & 0.72 & 24.24 & 29.85 & 28 \\
\hline & 1.57 & 49.36 & 0.69 & 31.46 & 31.35 & 91 \\
\hline & 0.83 & 55.13 & 0.70 & 66.80 & 34.84 & 182 \\
\hline & 0.66 & 44.78 & 0.76 & 67.85 & 23.81 & 365 \\
\hline \multirow{6}{*}{ جִ } & 0.52 & 46.51 & 0.67 & 89.44 & 30.73 & 3 \\
\hline & 0.80 & 46.02 & 0.43 & 57.24 & 46.97 & 7 \\
\hline & 1.07 & 53.98 & 0.64 & 50.32 & 36.98 & 28 \\
\hline & 1.18 & 48.87 & 0.62 & 41.54 & 34.86 & 91 \\
\hline & 0.58 & 51.70 & 0.61 & 89.54 & 37.20 & 182 \\
\hline & 0.49 & 51.89 & 0.62 & 101.79 & 31.18 & 365 \\
\hline
\end{tabular}

${ }^{\text {a }}$ Calculated from weight loss at $\sim 480^{\circ} \mathrm{C}$

${ }^{\mathrm{b}}$ Calculated from weight loss between $600-900^{\circ} \mathrm{C}$

${ }^{\mathrm{c}}$ Calculated from weight loss between $150-400^{\circ} \mathrm{C}$ 
Table 6. Open porosity (\%) in mortars tested after 365 days.

\begin{tabular}{|c|c|c|c|c|}
\hline \multirow{6}{*}{$\begin{array}{l}1: \\
1: \\
1:\end{array}$} & Ag-1 & Ag-2 & Ag-3 & Ag-4 \\
\hline & 28.86 & 30.06 & 27.95 & 29.34 \\
\hline & 22.10 & 27.20 & 25.47 & 26.63 \\
\hline & 19.96 & 25.80 & 24.72 & 25.77 \\
\hline & 18.04 & 25.63 & 23.80 & 24.72 \\
\hline & 18.03 & 23.48 & 23.01 & 24.12 \\
\hline
\end{tabular}




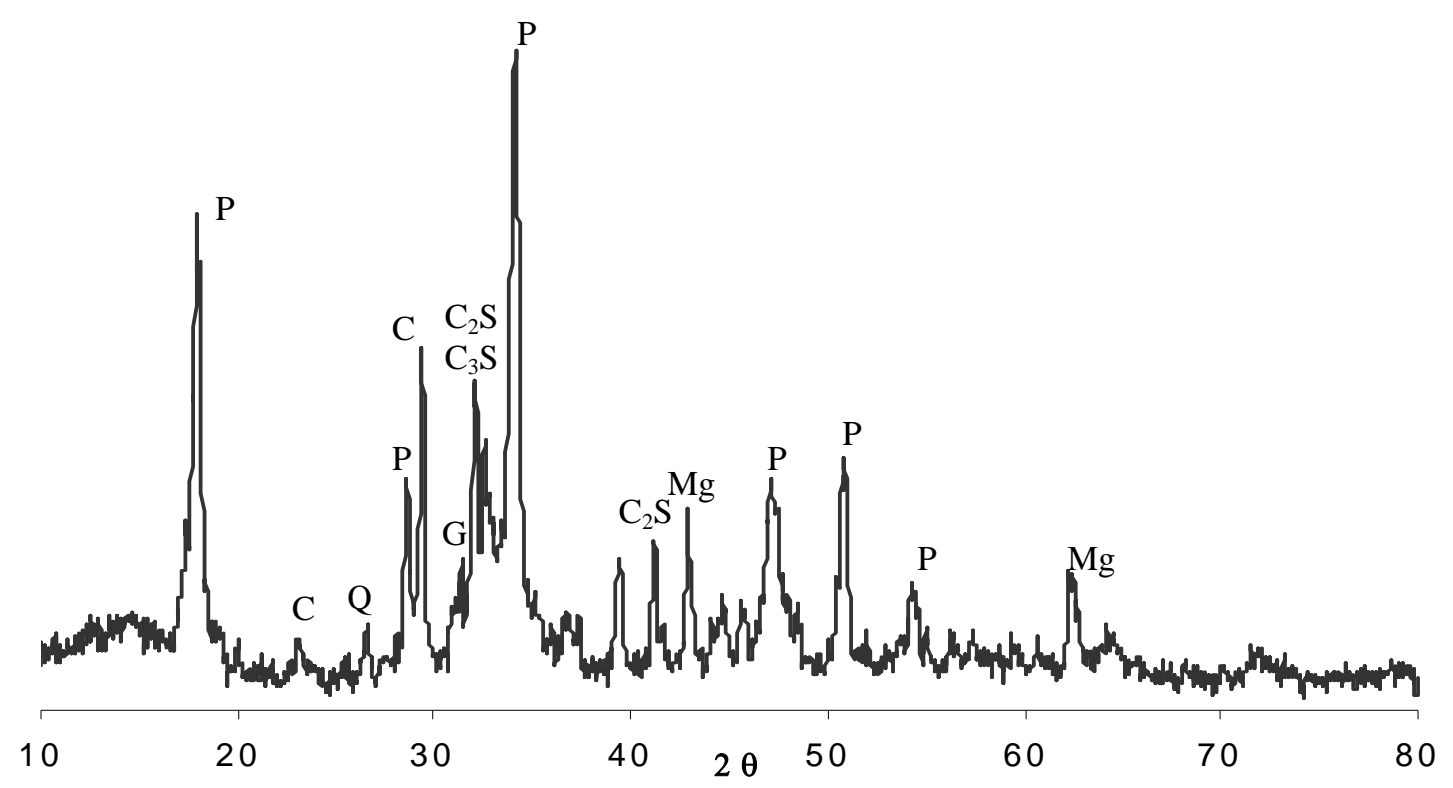

Figure 1. XRD of hydraulic lime. P: Portlandite; C: Calcite; Q: Quartz; Mg: Periclase; $\mathrm{C}_{2} \mathrm{~S}$ : Dicalcium silicate; $\mathrm{C}_{3} \mathrm{~S}$ : Tricalcium silicate; G: Gehlenite. 


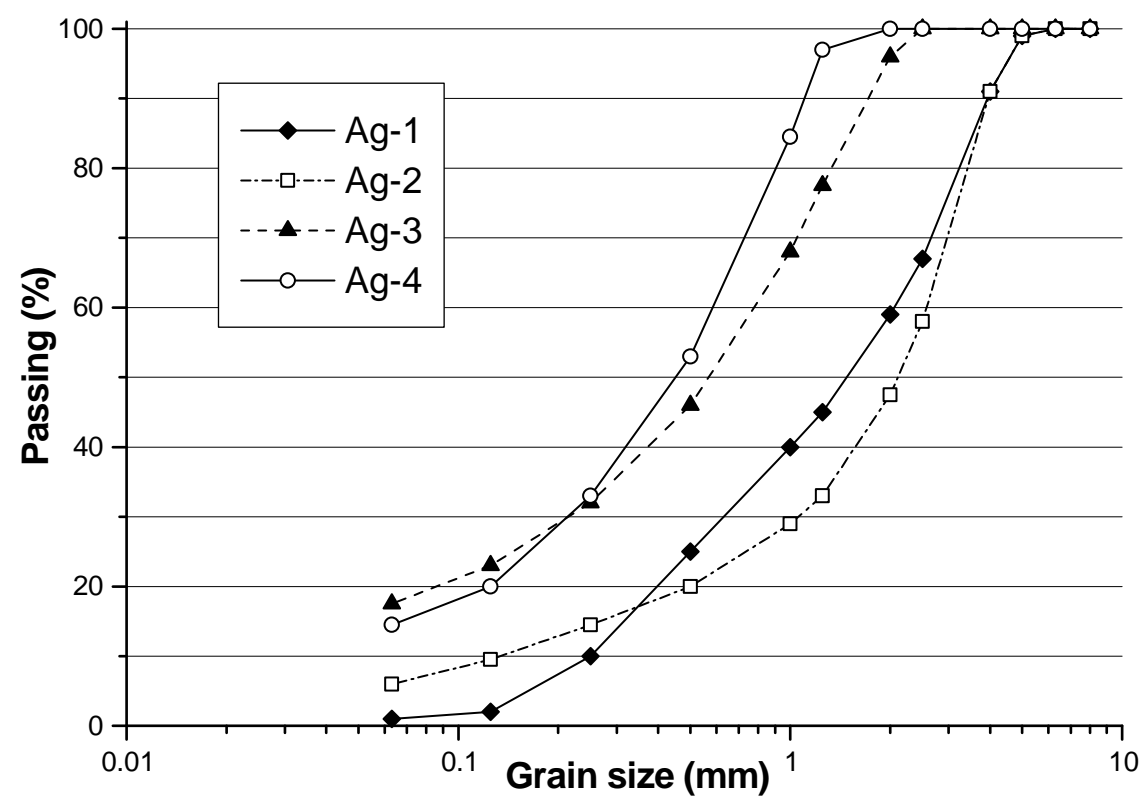

Figure 2. Grain size distributions of the aggregates. 


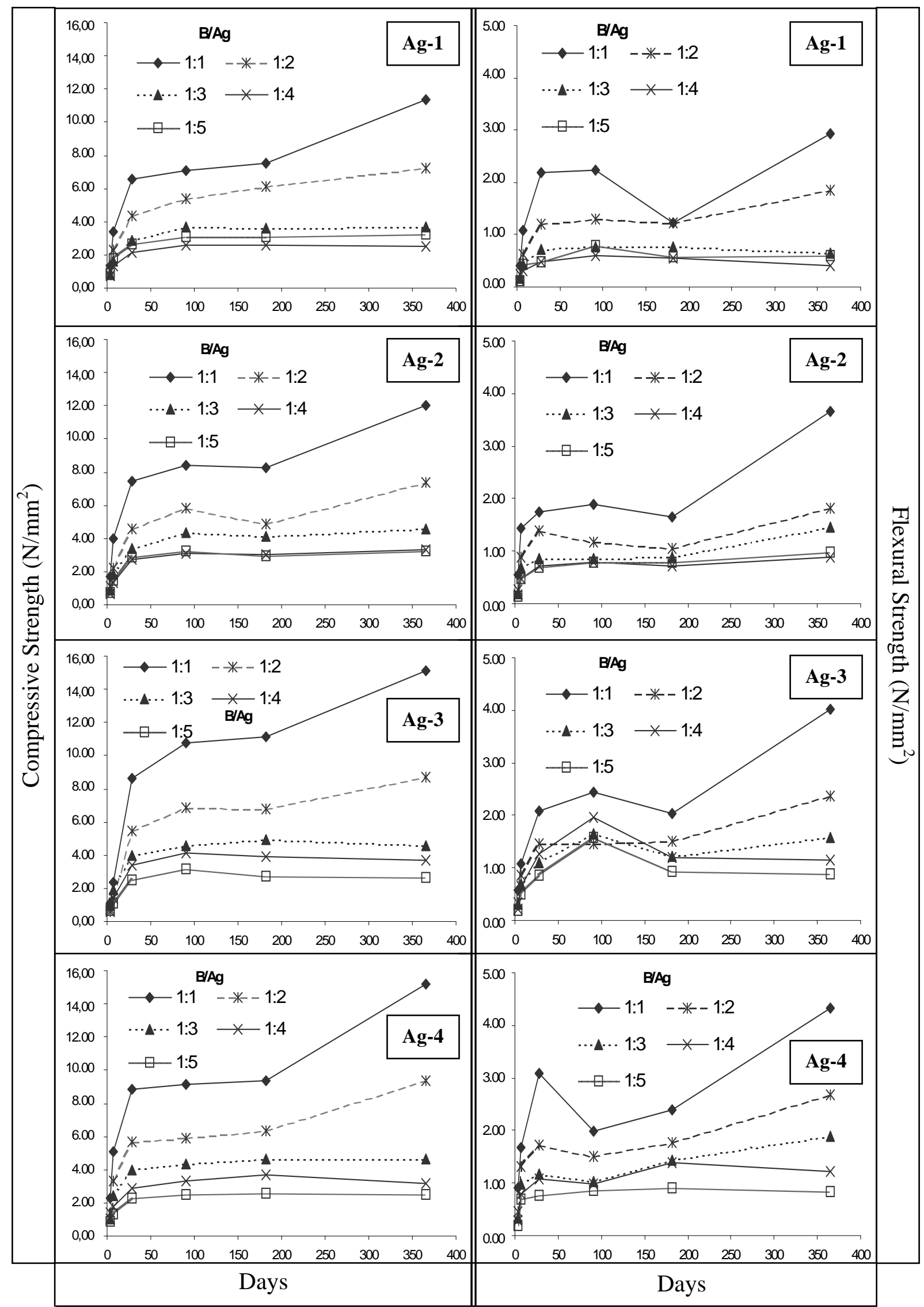

Figure 3. Strength results in hydraulic lime mortars with different aggregates vs. curing time. 


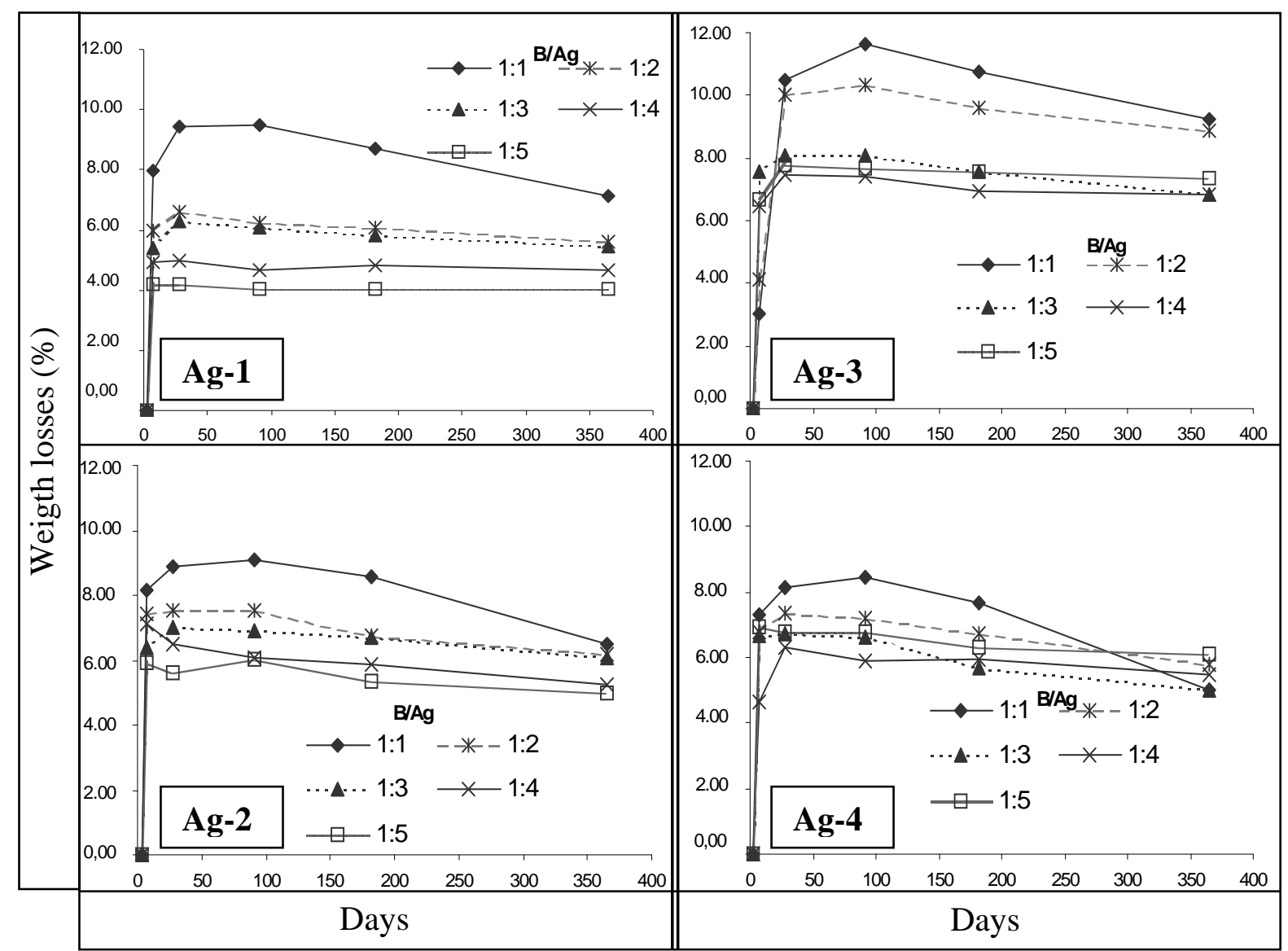

Figure 4. Weight losses vs. curing time in hydraulic lime mortars with different aggregates. 


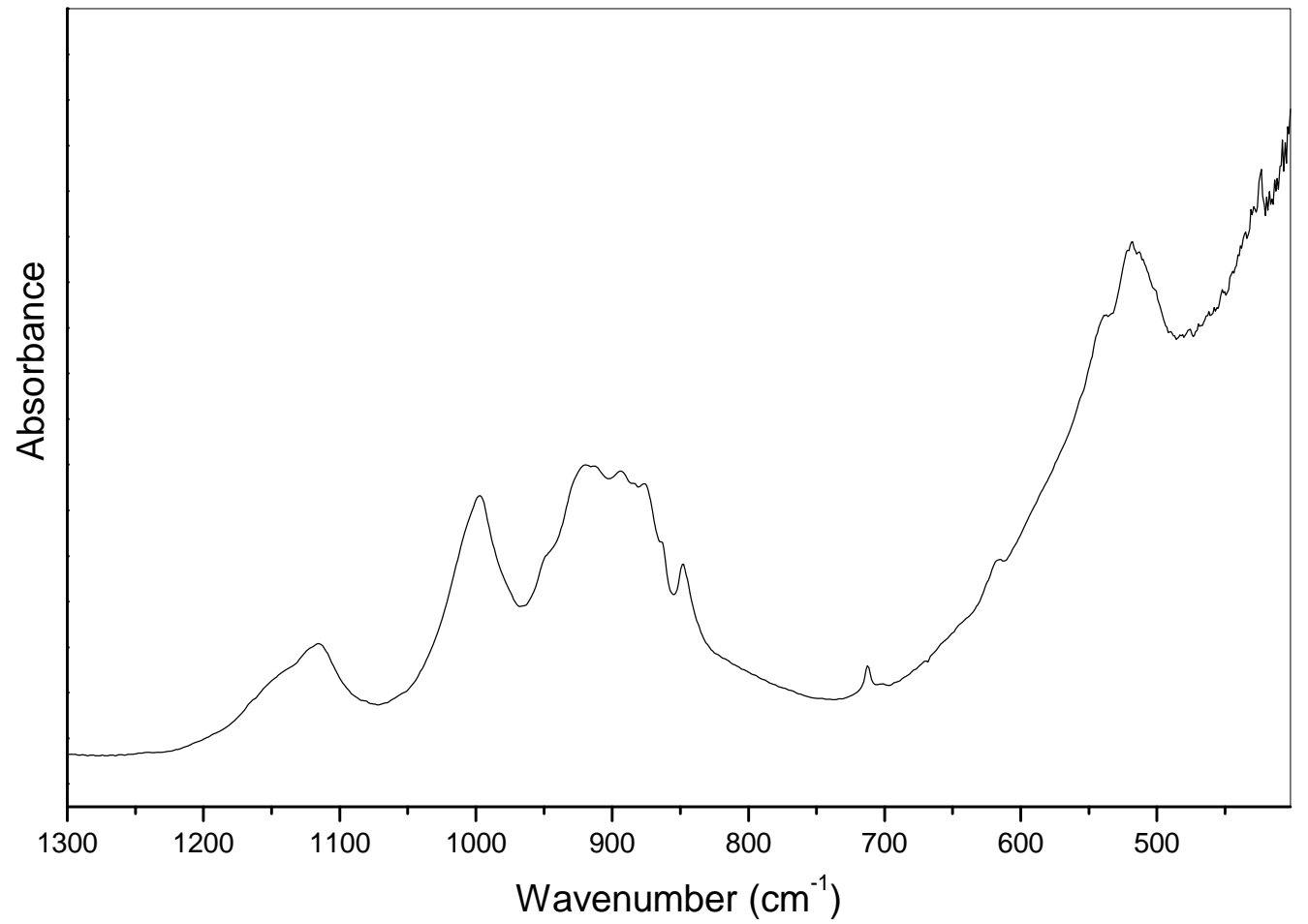

Figure 5. Infrared spectrum of NHL in the $1300-400 \mathrm{~cm}^{-1}$ region. 


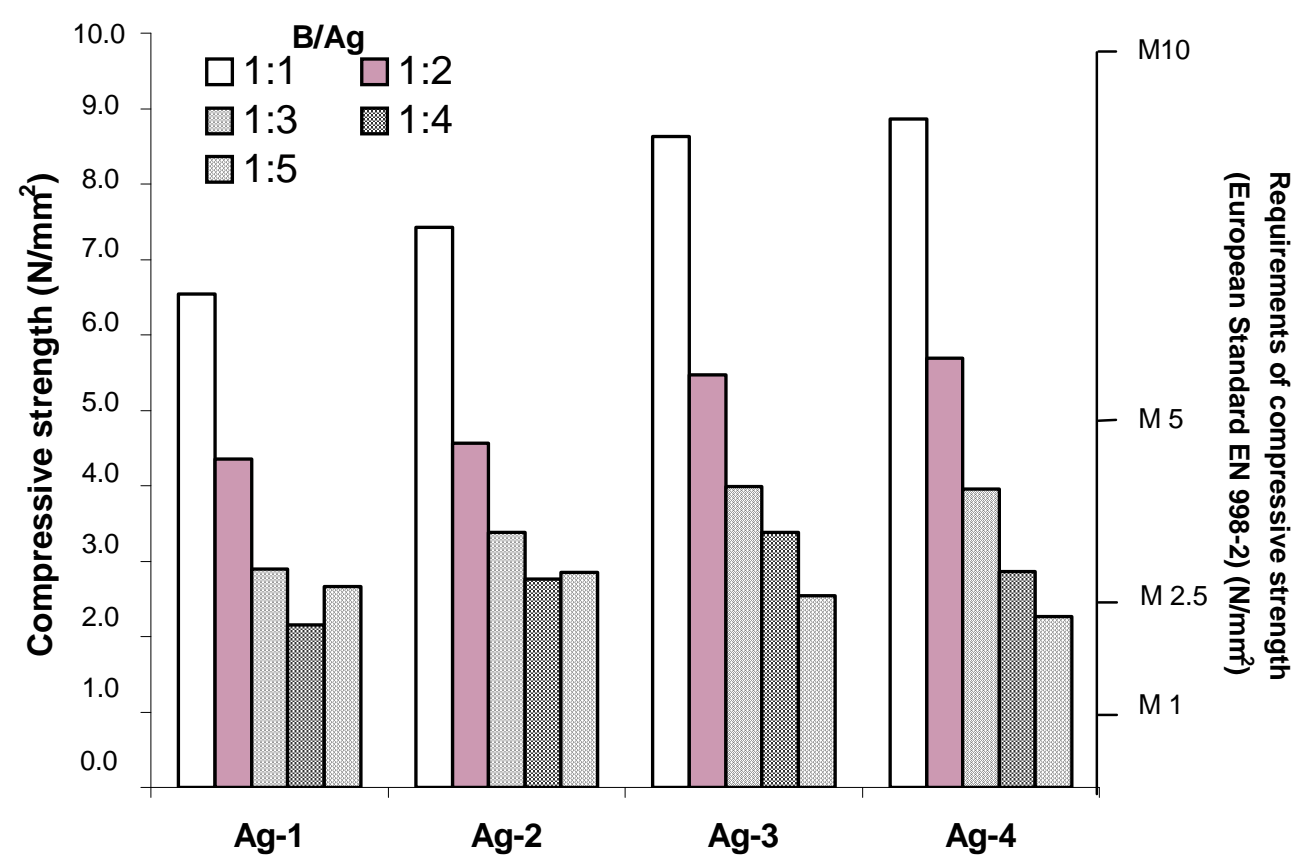

Figure 6. Comparison between compressive strength results (28 curing days) and European Standard (EN 998-2) values of the different classes of mortar. 


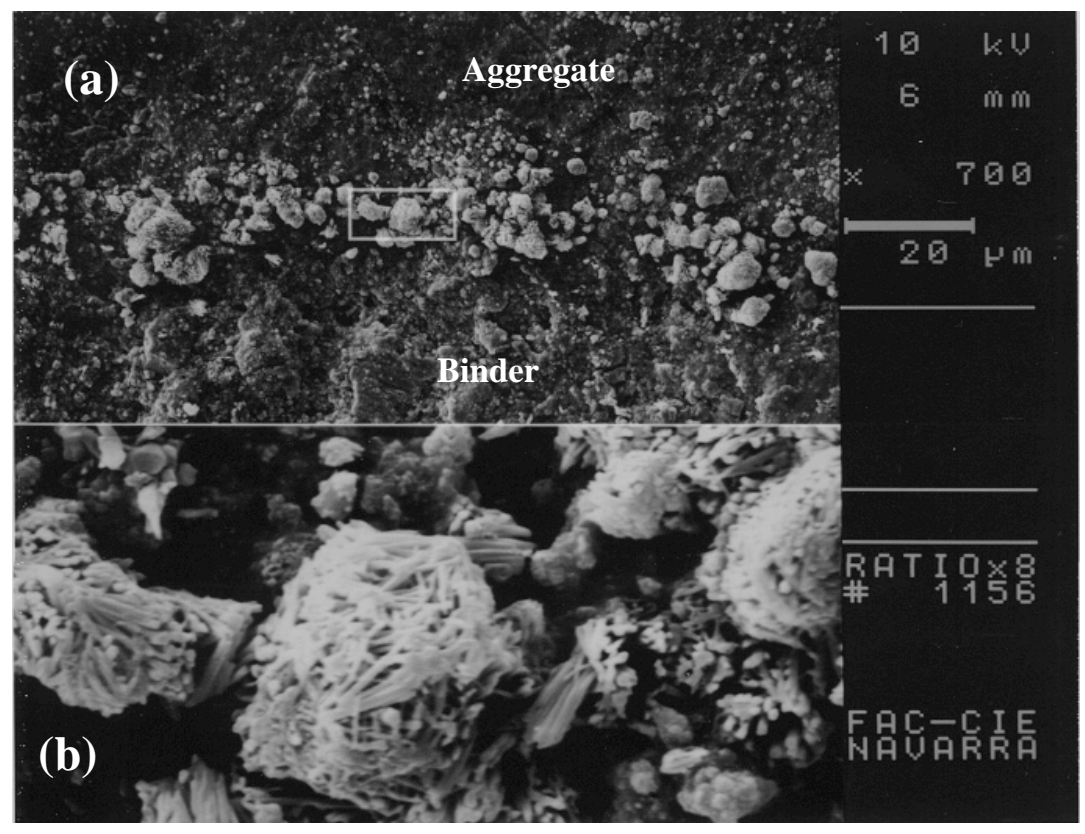

Figure 7. SEM micrograph of (1:1) B/Ag mortar with Ag-3. (a) Interface binder-aggregate. (b) Enlargement showing CSH structures. 

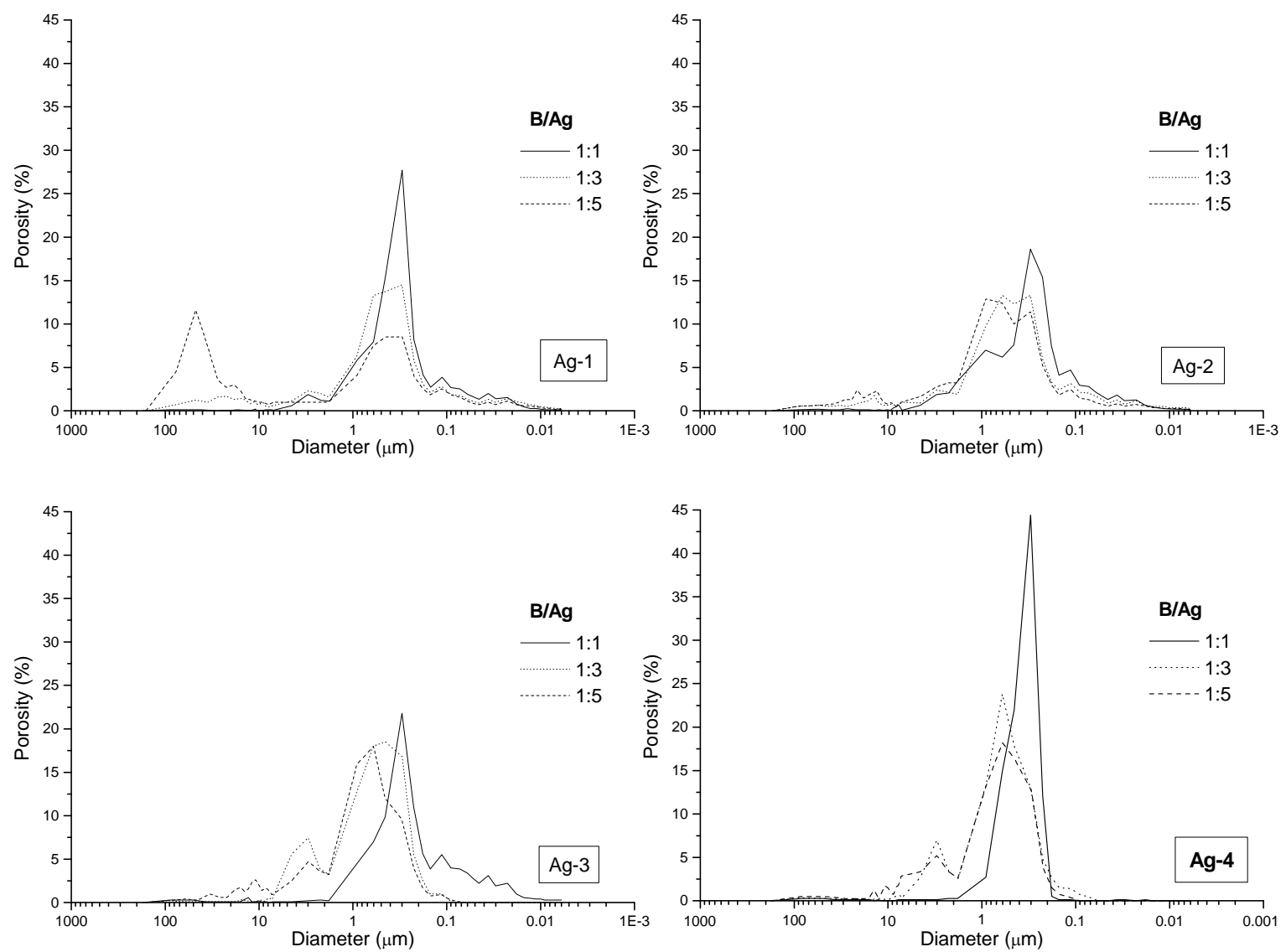

Figure 8. Results from mercury intrusion: Pore size distribution for hydraulic mortars with different aggregates at 365 days. 


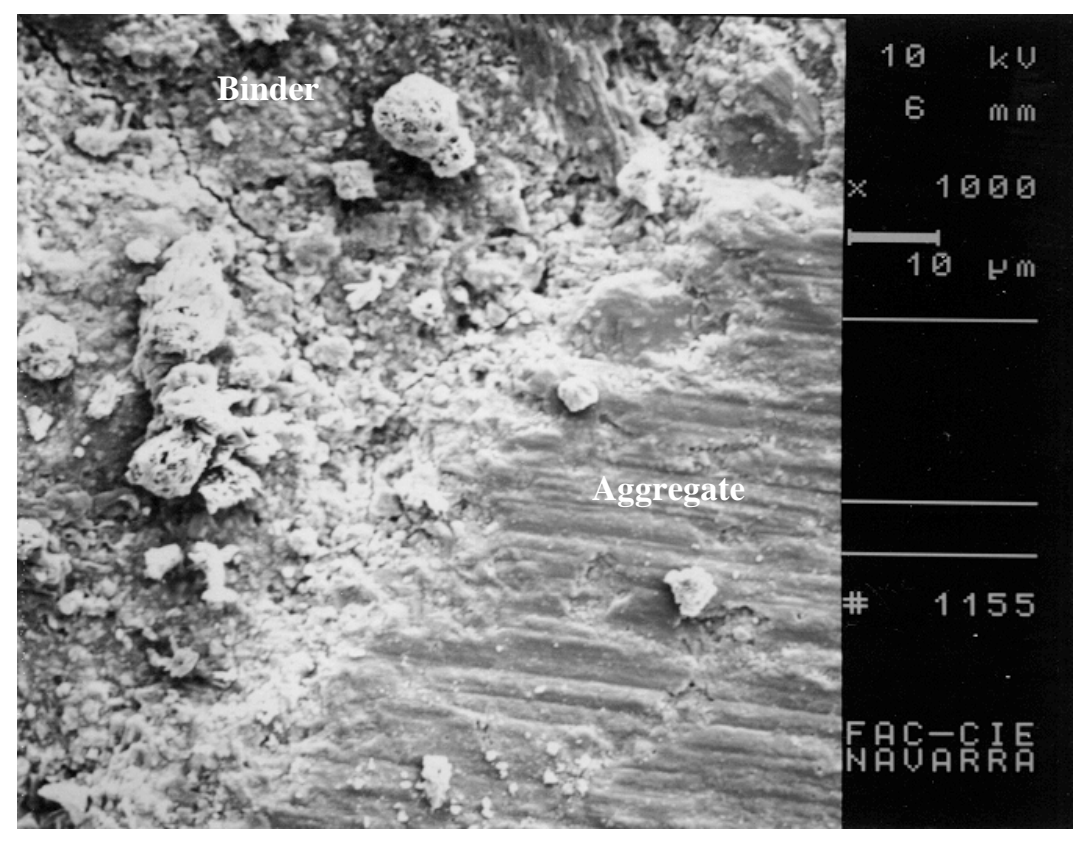

Figure 9. SEM micrograph of (1:1) B/Ag mortar with Ag-4. Interface binder aggregate. 